\title{
Large-scale karst features and open taliks at Vardeborgsletta, outer Isfjorden, Svalbard
}

\author{
OTTO SALVIGSEN AND ANNE ELGERSMA
}

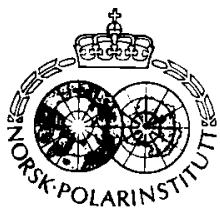

Salvigsen, O. \& Elgersma, A. 1985: Large-scale karst features and open taliks at Vardeborgsletta, outer Isfjorden, Svalbard. Polar Research 3 n.s., 145-153.

Ground temperature measurements show that open taliks occurring at Vardeborgsletta are probably caused by the heat of circulating water from great depths. The absence of permafrost has allowed the ground water to circulate, and large-scale karst features have developed in a limestone area. Karst processes are also active today, and dolines and ponds with sinking drainage occur.

Otto Salvigsen, Norsk Polarinstitutt, Rolfstangveien 12, 1330 Oslo Lufthavn, Norway; Anne Elgersma, Geologisk institutt, Avdeling B, Allégt. 41, 5000 Bergen, Norway.

The area north of Linnévatnet (Figs. 2 and 3 ) has a great variety of periglacial forms and features which have been mapped and studied in detail by Åkerman (1980). The geology of the area was studied by expeditions from Norsk Polarinstitutt in 1983 and 1984, during which attention was paid to the anomalous occurrence of large basins with subsurface drainage (Figs. 3, 4 and 5).

Åkerman (1980) interpreted these large-scale features to have been formed mainly by active thermokarst processes and that consequently the drainage should go through intrapermafrost

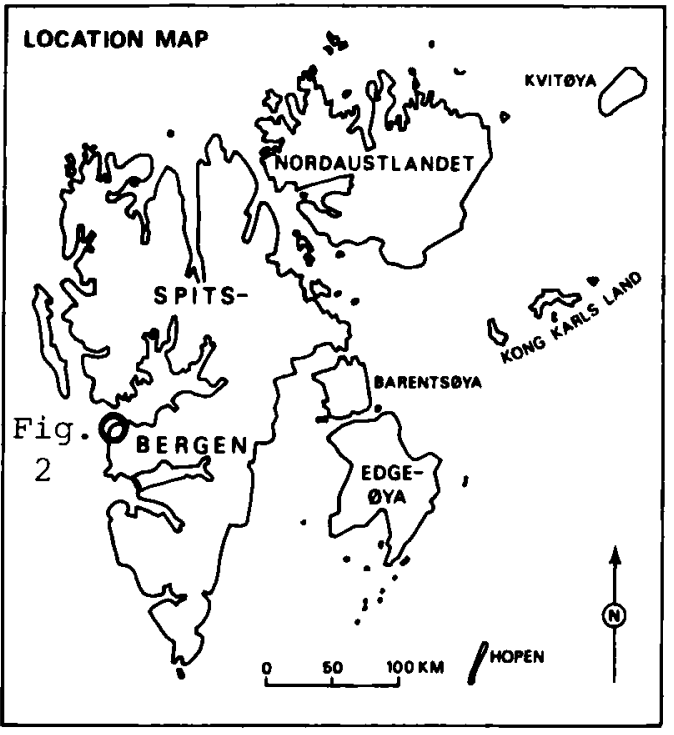

Fig. 1. Location map. Svalbard. taliks. He discussed, however, whether thermokarst and/or common karst was responsible for the morphology and hydrography of the area. Polish scientists have also made geomorphological studies in this area, and Gogolek \& Lewandowski (1980) described a 'vast thermokarst trough formed by three thermokarst bowls'.

Unconsolidated sediments are usually not thick and extensive in Svalbard, and it was therefore difficult to imagine that these basins could have been formed solely by the melting of ice in unconsolidated sediments. Karst development in the underlying calcareous bedrock seemed to be the more likely explanation. A closer examination of the area revealed the existence of large karst features combined with high ground temperatures.

\section{Karst in Svalbard and other Arctic areas}

Karst is much more usual in areas with discontinuous permafrost (e.g. Brook 1983) than in areas with continuous permafrost, but observations of surface karst features have been made in many high arctic areas. Reports from Svalbard by Corbel $(1957,1960,1964)$, Helldén (1974), and Åkerman (1983) can be mentioned. Continuous deep permafrost inhibits subsurface drainage, and underground karst is not developed on any extensive scale (Brook \& Ford 1978; Palmer 1984). On the Siberian platform, however, several areas under permafrost conditions exhibit a well-developed karst morphology (Popov et al. 1972), with 


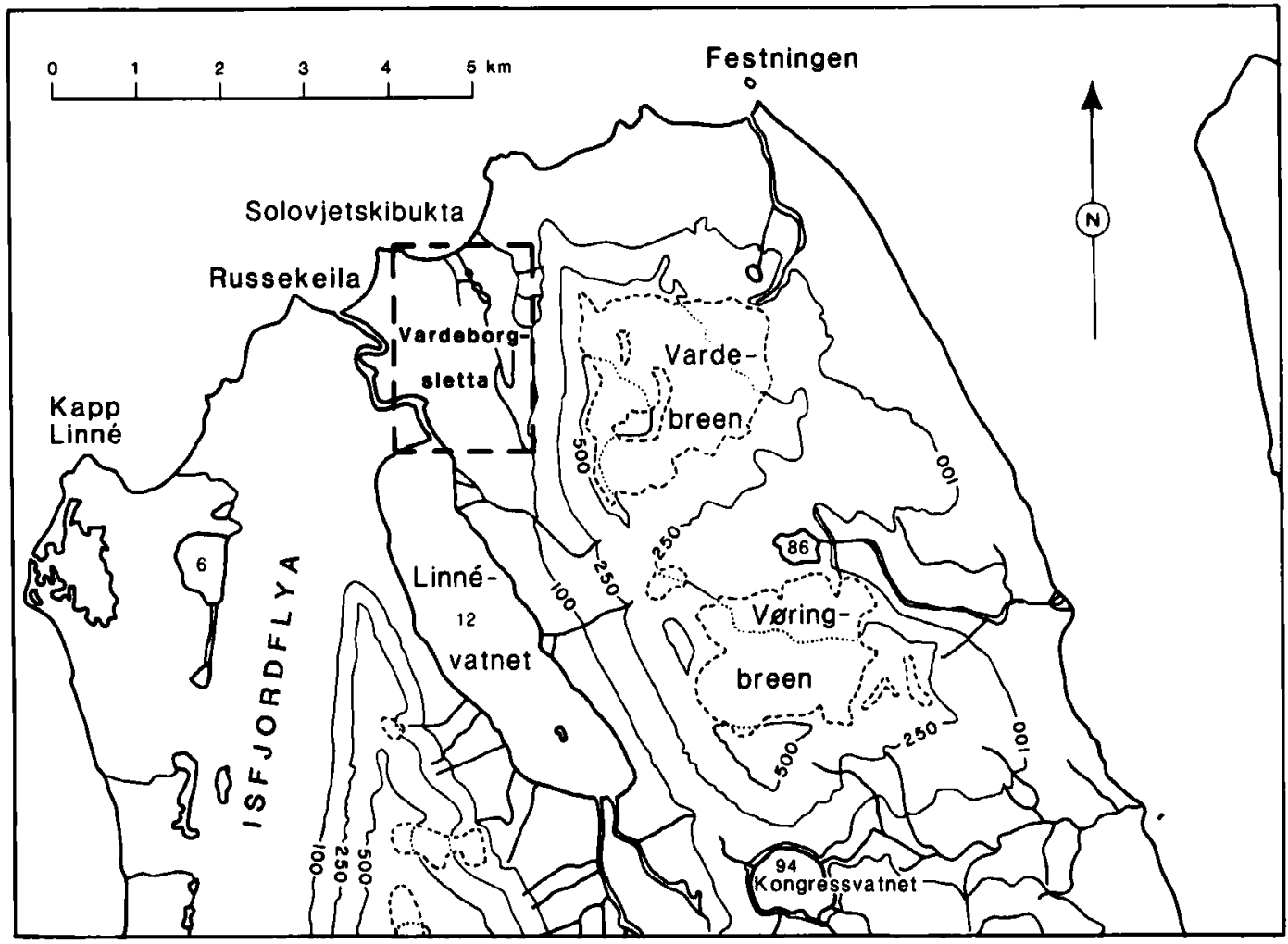

Fig. 2. Location map, Vardeborgsletta and surroundings.

karstification occurring under especially favourable geomorphological and geological conditions. Gypsum and salt karst have formed, in addition to that formed in the carbonate rocks. In other high arctic localities karst seems to be more limited, but some large-scale features have also been located in Svalbard.

Barbaroux \& Besset (1968) have described large karst features from Sarsøyra (south of Kongsfjorden). One polje forms an elliptic depression, $100 \mathrm{~m} \mathrm{~N}-\mathrm{S}$ and $200 \mathrm{~m} \mathrm{E}-\mathrm{W}$, with a maximum depth of $6 \mathrm{~m}$. Salvigsen et al. (1983) described karst in gypsum in the inner Isfjorden area, mainly sinkholes and dolines with associated forms. Baranowski (1974) reported a great number of karst out-flows and ponors as well as cave mouths from the western part of Sørkapp Land, but details have not so far been given about the karst features in this area. Pulina (1974) discussed some karst phenomena in the Hornsund region and described a $30 \mathrm{~m}$ long cave.

\section{Physical setting of the study area}

The bedrock geology is shown on a map in the scale 1:500,000 (Flood et al. 1971). It is also described by Worsley \& Mørk (1981), but no detailed geological mapping has been carried out. The area with karst features has a cover of unconsolidated sediments, and the underlying bedrock can only be seen in a few places. The rocks are mainly fossil-rich limestones, and on outcrops reveal solution surfaces. Gypsum, which is also easily soluble, was observed at one locality. It would appear that the karst has developed in the ground along the strike of this Upper Carboniferous-Permian bedrock.

The unconsolidated sediments are predominantly of marine origin, and have a surface cover of shoreline-derived facies. A section along Linnéelva shows a thin layer of till overlying a thick layer of marine sand. The age of this till is not determined, but ongoing investigations in the area indicate that most of the unconsolidated sedi- 


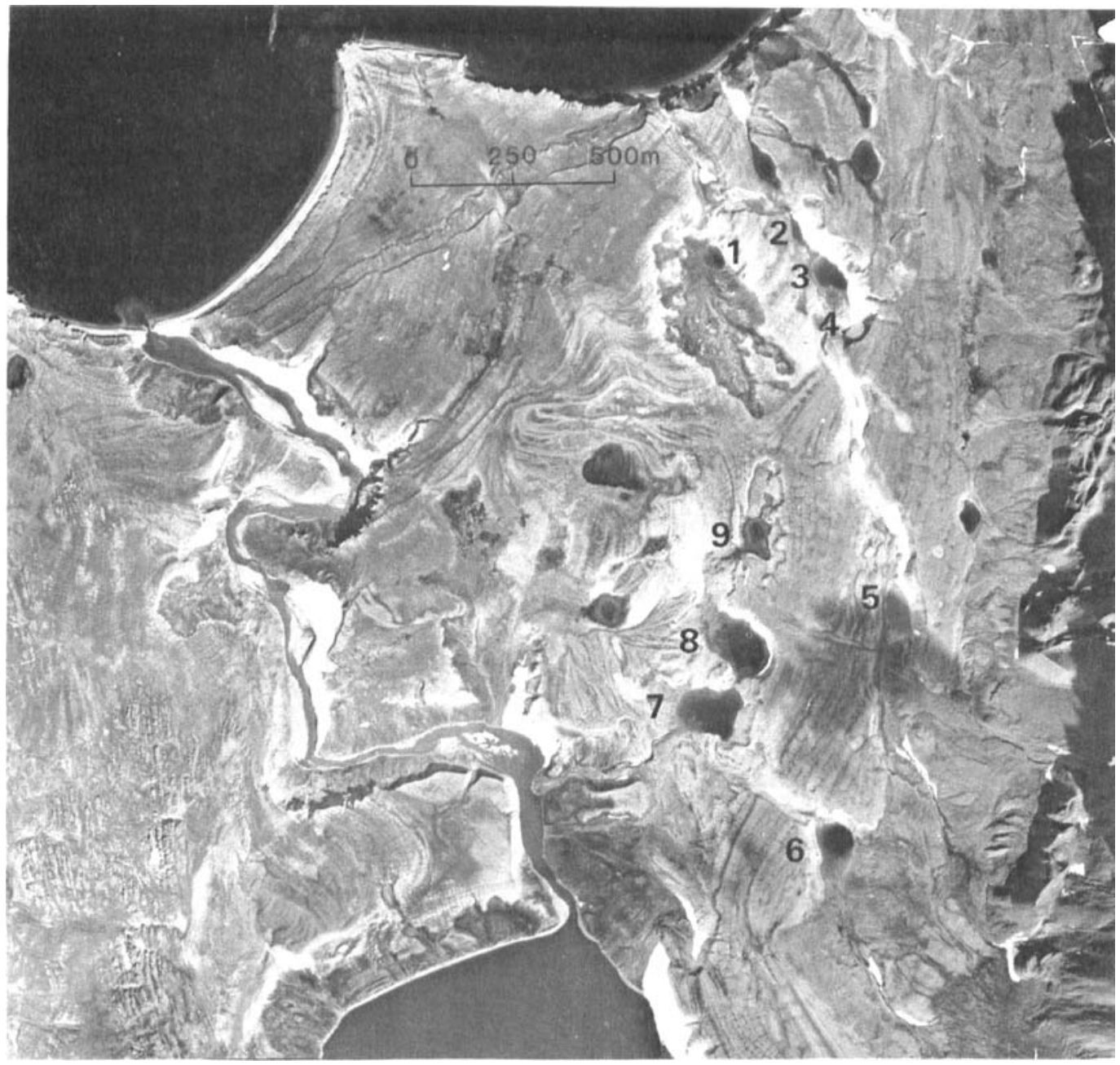

Fig. 3. Air photo of Vardeborgsletta ( 6992436 ). Numbers refer to depressions with ponds mentioned in the text. See also Fig. 4.

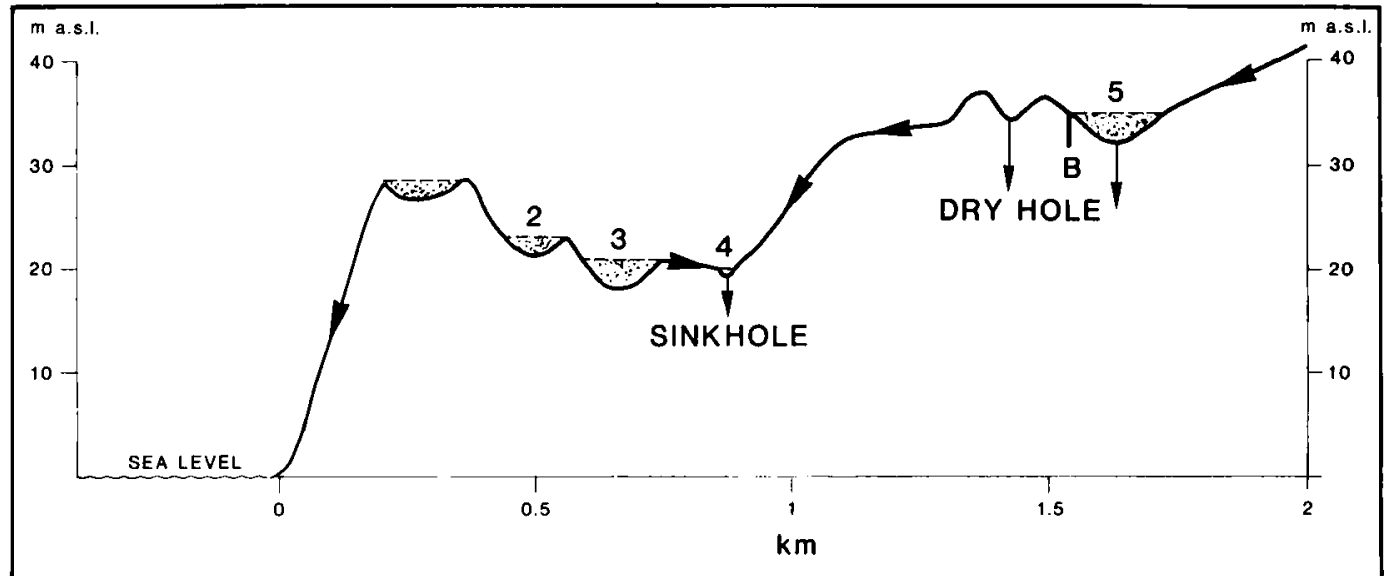

Fig. 4. Schematic and simplified section along the main karst depression at Vardeborgsletta (see Fig. 3). 


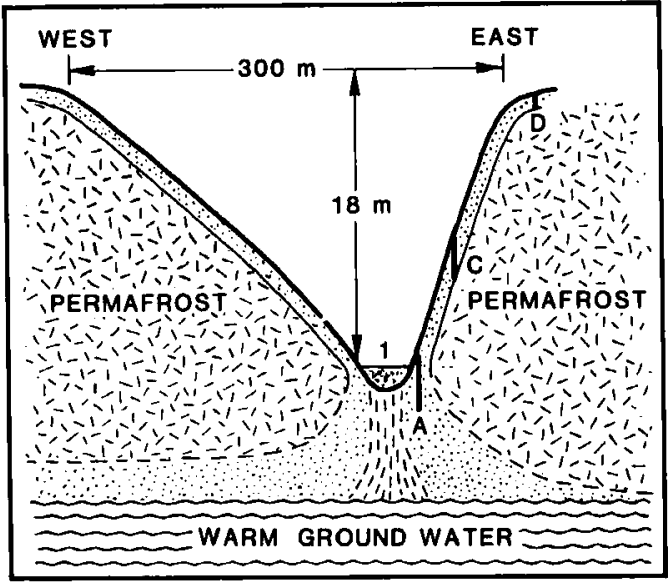

Fig. 5. Schematic and simplified section across basin with pond 1. Locations of pits $A, C$ and $D$ are also shown.

ments at Vardeborgsletta are of pre-Late Weichselian age capped by a layer of Holocene beach sediments. The Holocene marine limit is about $55 \mathrm{~m}$ above sea level, which is well above the large karst features.

The annual mean temperature in the study area is approximately $-4.5^{\circ} \mathrm{C}$ as measured at Isfjord Radio station for the period 1946-1975 (Steffensen 1982). The mean temperature for the warmest month (July) in the same period was $4.7^{\circ} \mathrm{C}$, and in March, the coldest month, the mean temperature was $-12.2^{\circ} \mathrm{C}$. The mean annual precipitation for the period 1934-1975 at Isfjord Radio has been calculated at $400 \mathrm{~mm}$. According to Köppens classification the area has a true tundra climate.

The entire area of Svalbard has been considered to lie well inside the zone of continuous permafrost (Liestøl 1977; Åkerman 1980). The observed thickness of permafrost in Svalbard shows variations between 75 and $450 \mathrm{~m}$. In the mines of Barentsburg about $10 \mathrm{~km}$ east of Vardeborgsletta, permafrost reaches a depth of about $200 \mathrm{~m}$ (verbal comm. from Russian geologists).

\section{Basins with sinking drainage}

As shown on the aerial photography (Fig. 3), large depressions with internal drainage occur in the eastern part of Vardeborgsletta. The most significant features form an almost $2 \mathrm{~km}$ long trough-shaped valley which extends from the sea

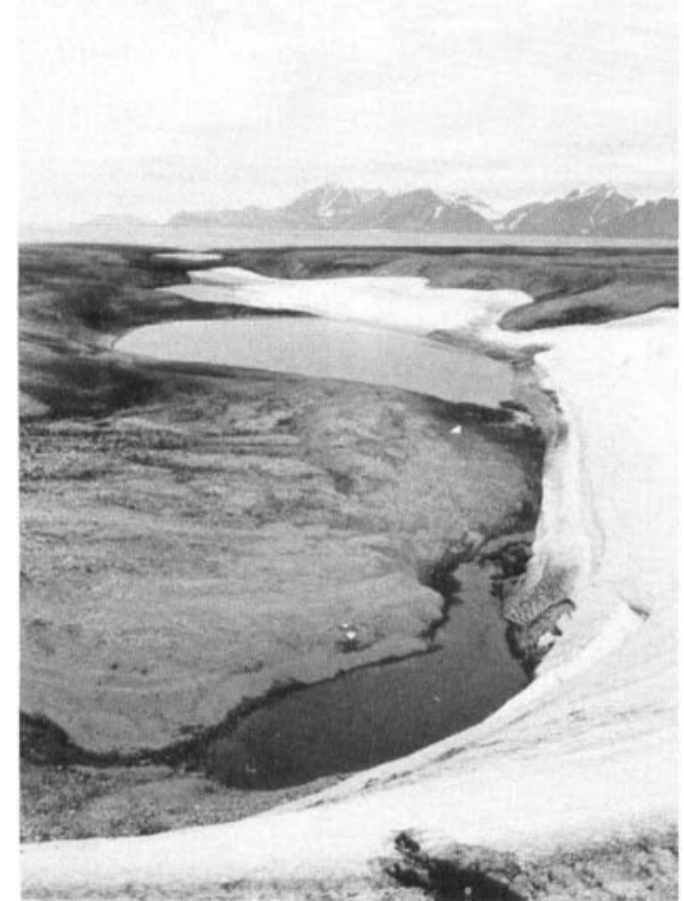

Fig. 6. Ponds 2 and 3 with the swallow hole, 4 , in the foreground where the water drains into coarse sediments below the snow field.

to pond 5. Water from this valley runs off into a sinkhole (4) located in the middle of the depression. The main contribution of runoff to the sinkhole is the melting of snow and ice near ponds 2 and 3 (Figs. 6 and 7). Rough estimates of water running into the sinkhole from the north were about $100 \mathrm{l} / \mathrm{s}$ at the end of July 1983, and also in the same period in 1984. A tiny stream of water at the same time reached the sinkhole from the south.

The eastern slopes of the trough are steep, causing pebbles and cobbles to slide down into the snowdrifts. The other slopes of the trough are less steep and consequently more stable. The sinkhole is occupied by a $5 \mathrm{~m}$ long and $3 \mathrm{~m}$ wide pool, and a very efficient drainage is effected by the well-rounded beach cobbles of the eastern side (Fig. 7). The water depth in the pool was about $1 \mathrm{~m}$, and lies about $8 \mathrm{~m}$ below the threshold level for surface outflow to the sea. Old shoreline marks can be seen up to this level, but they have probably been formed many years ago when drainage through the sinkhole was less efficient. There were no signs of much higher water levels 


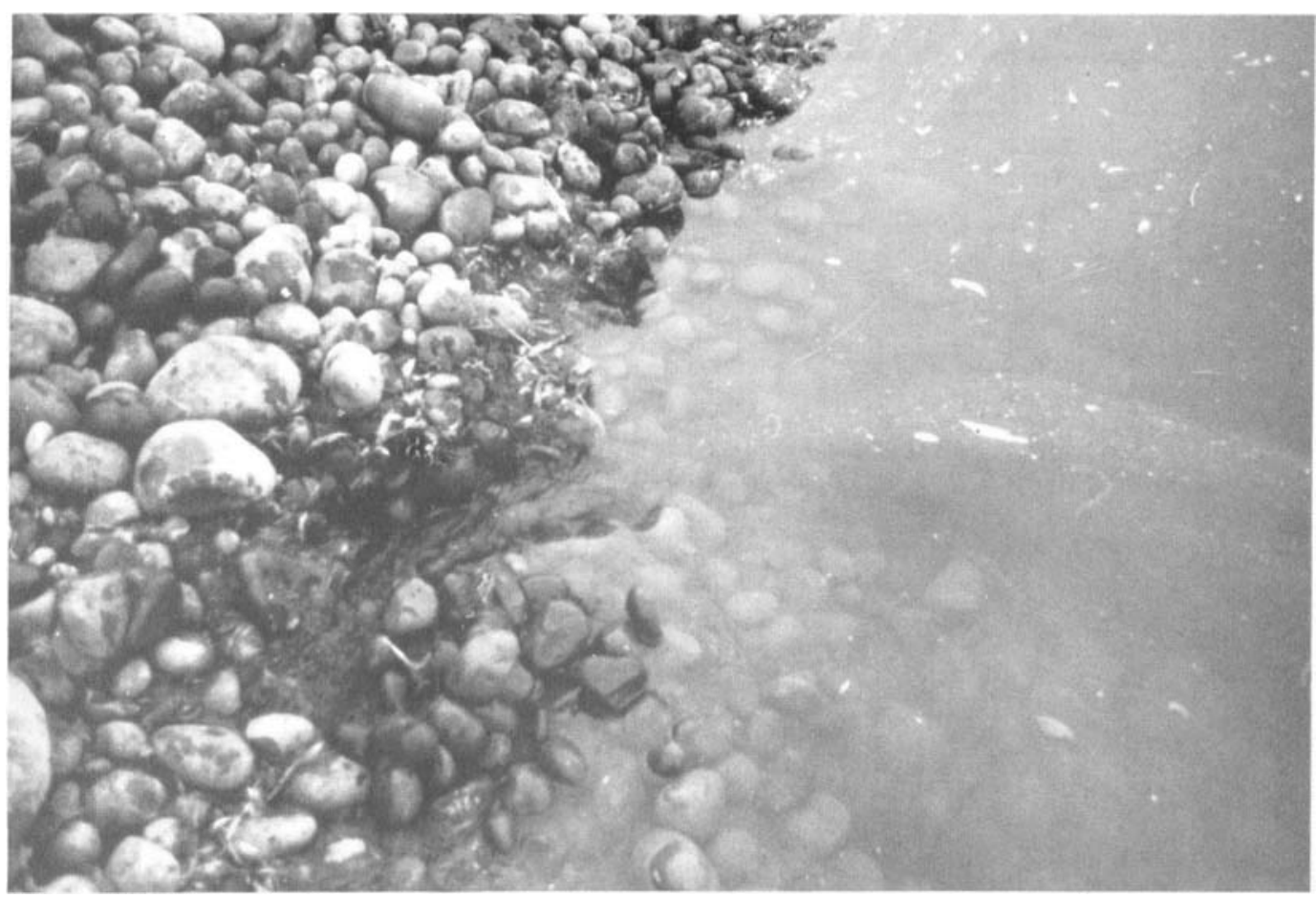

Fig. 7. Streaming water disappearing in the coarse sediments mentioned in Fig. 6.

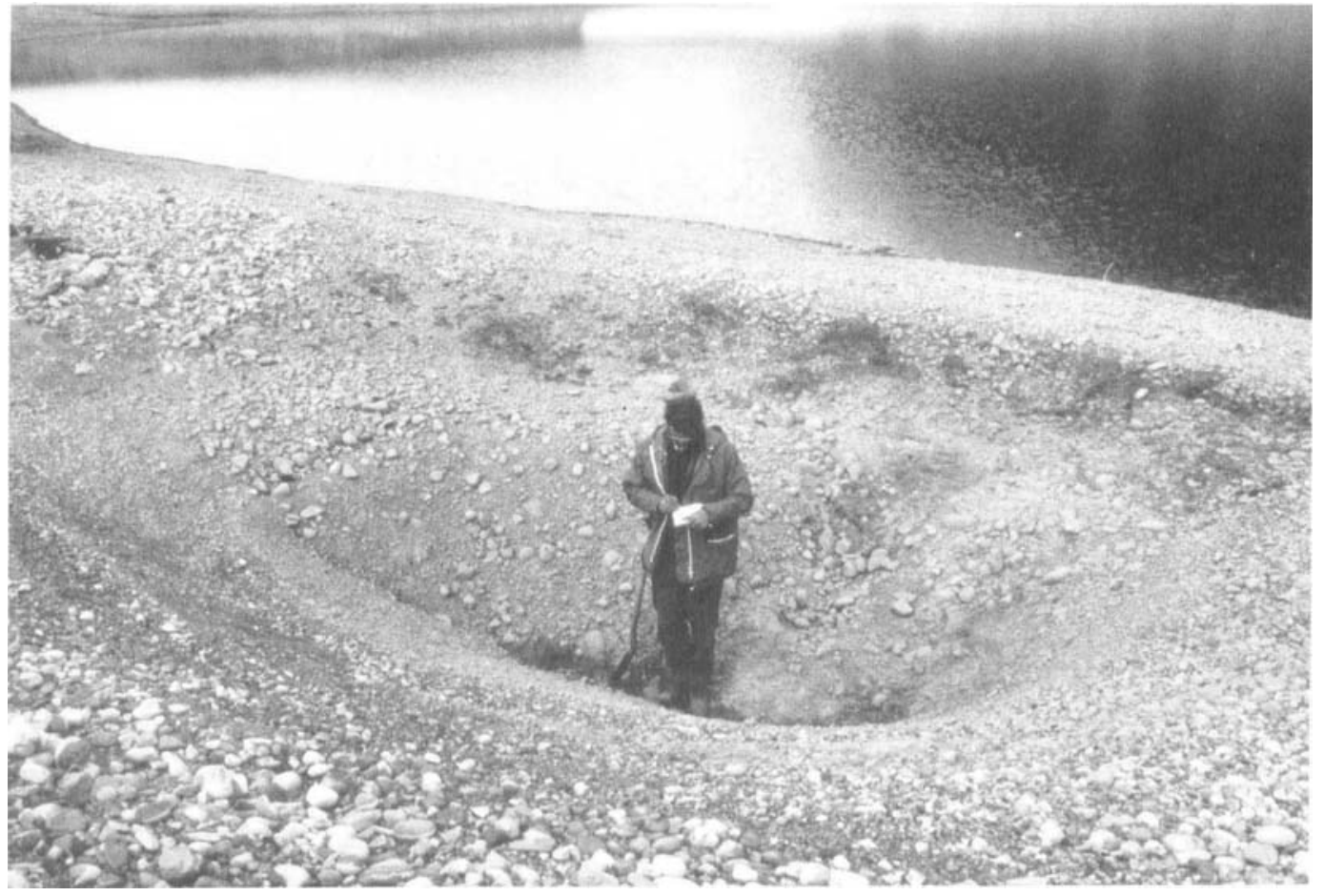

Fig. 8. Collapse feature at Vardeborgsletta near pond 6. 
from the previous years. A line of bird feathers showed that the highest water level in 1984 had been less than one metre higher than that of 1 August 1984, and a similar observation was made in 1983. Water level observations were made between 16 July and 3 August in 1983, and between 15 July and 15 August in 1984, and show that the water level variations in the sinkhole pool were less than $0.15 \mathrm{~m}$ in spite of some heavy rainfalls. The constancy of the water level in this pool would indicate a large drainage capacity through coarse sediments.

During the observation periods, pond 5 had a slightly sinking water level (less than $0.1 \mathrm{~m}$ ) which was more than $2 \mathrm{~m}$ below the level for surface drainage. The western shore up to this level was covered by a silt accumulation vegetated by grass. The altitude is $35 \mathrm{~m}$ above sea level, and the measured maximum depth was $3 \mathrm{~m}$. North of pond 5 there is a dry hole which seems to be filled with water only during the short periods of snowmelting.

Pond 6 has a summertime water level about $4 \mathrm{~m}$ below the level of the surface drainage which in that case would go to Linnéelva. Water level variations were less than $0.25 \mathrm{~m}$ in the observed periods. The altitude of the pond is $42.5 \mathrm{~m}$ above sea level, and its shores exhibit several collapse features and structures (Fig. 8).

An asymmetric basin containing a shallow pond (1) is located west of the trough described above. Its water level is $17.5 \mathrm{~m}$ above sea level and $8 \mathrm{~m}$ below a level where surface drainage would take place. Water level variations of a maximum of $0.8 \mathrm{~m}$ were seen during the observed periods, and old shoreline marks could be seen up to $5 \mathrm{~m}$ higher. The bird feather level of 1984 was only about $1 \mathrm{~m}$ above the observed maximum water level. Thus, the drainage capacity of the sediments would seem to be rather large. A small pit where water runs off down through the sediments was observed on the bottom of the pond near the eastern shore. One collapse feature was also seen on the eastern slope about $1 \mathrm{~m}$ above the water level. The eastern side is steepest and has the coarsest material. As can be seen from Fig. 3, the other slopes have very active solifluction processes which bring considerable amounts of material down to the bottom of the basin. A very rough calculation of the volume of the basin

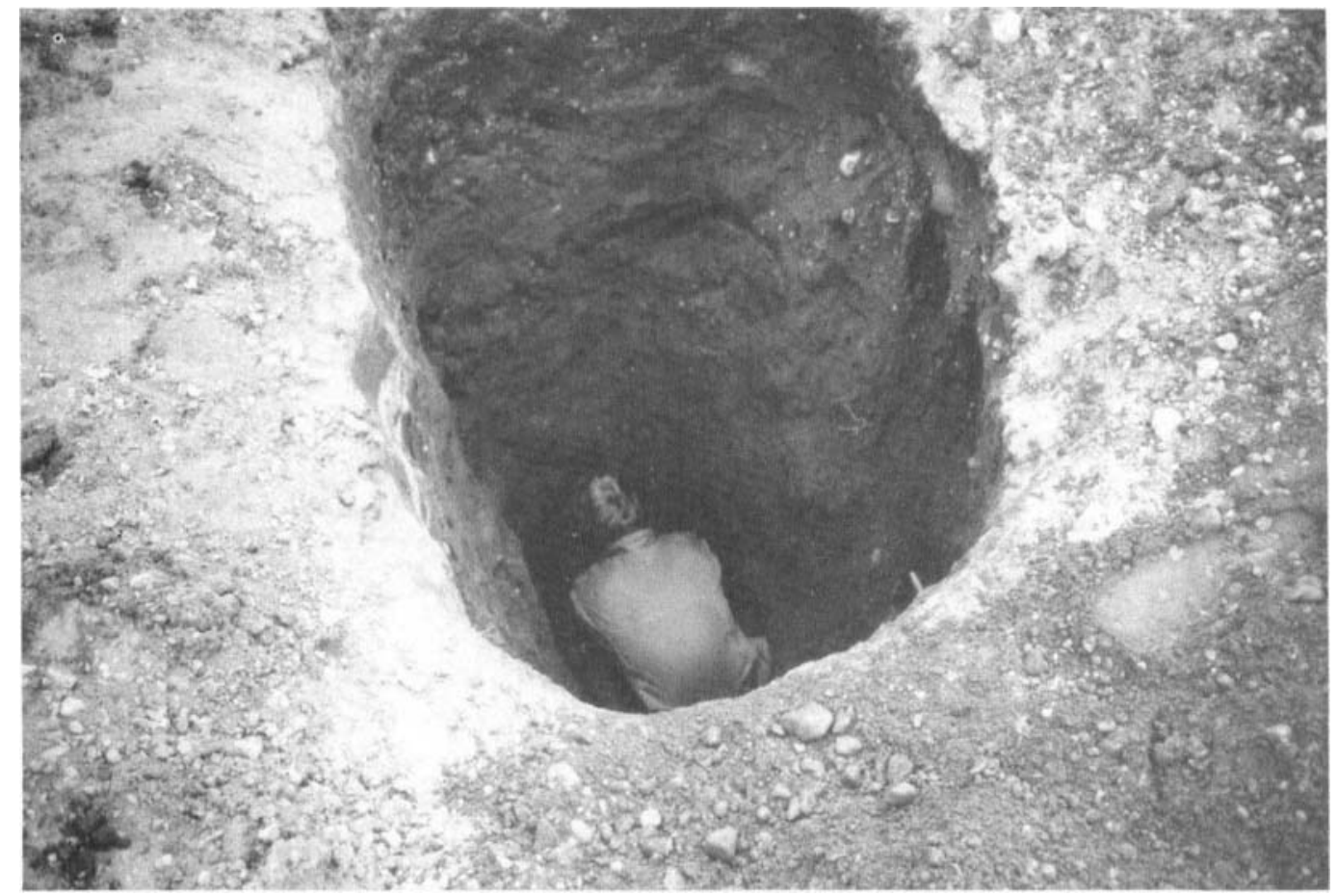

Fig. 9. From the digging of the $3.3 \mathrm{~m}$ deep pit at Vardeborgsletta. 
Table 1. Ground temperatures at Vardeborgsletta 1984. See text and Figs. 4 and 5 for location of pits A-D.

\begin{tabular}{|c|c|c|c|c|c|c|c|c|c|c|c|}
\hline Depth (m) & 0 & 0.5 & 1.0 & 1.15 & 1.2 & 1.5 & 2.0 & 2.5 & 2.9 & 3.0 & 3.3 \\
\hline$A(19.7)$. & 10.5 & 10.6 & 9.8 & & & 10.0 & 10.1 & 10.2 & & 10.5 & 10.7 \\
\hline В (28.7.) & 10.9 & 8.1 & 6.8 & & & 5.8 & 4.3 & 4.2 & 4.4 & & \\
\hline$C(21.7)$. & 9.6 & 5.8 & 2.2 & 0 & & & & & & & \\
\hline $\mathrm{D}(21.7)$. & 10.6 & 6.8 & 2.2 & & 0 & & & & & & \\
\hline
\end{tabular}

produced an estimate of approximately 600,000 cubic metres.

\section{Ground temperatures}

Extensive subterranean drainage in areas of continuous permafrost is difficult to understand and explain and ground temperature measurements were therefore taken near two of the ponds with sinking drainage. Pits were dug by hand as deep as it was considered safe to work (Fig. 9). At basin 1, pit A was dug on the north-eastern shore of the pond, $1.5 \mathrm{~m}$ above the water level of 19 July 1984 . A depth of $3.3 \mathrm{~m}$ was reached through varying layers of sand and gravel of well-rounded stones. The pit wall was transected by small-scale faulting, suggesting that mass transport into this side of the basin had been caused by rapid movements in the ground beneath. The temperature was measured on the surface and at intervals of $0.5 \mathrm{~m}$ of depth. The results are shown in Table 1 and Fig. 9. As can be seen, the temperature was unexpectedly high, especially at a depth of $3.3 \mathrm{~m}$, where the ground temperature was $10.7^{\circ} \mathrm{C}$.

Another pit, B, was dug, near pond 5 and only $0.7 \mathrm{~m}$ above the water level of the pool. The results of Table 1 and Fig. 10 show lower ground temperatures than in pit A. It is, however, significant that the temperature increases between the 2.5 and $2.9 \mathrm{~m}$ depths. This implies a geothermal heat which prevents the formation of permafrost also in this location.

Two pits were dug to control the depth of permafrost in adjacent areas east of pond 1. Pit $C$ was dug in the slope $7.5 \mathrm{~m}$ above pond 1 , and permafrost was found at a depth of $1.15 \mathrm{~m}$. Pit $\mathrm{D}$ was dug on the top level between ponds 1 and 2 about $18 \mathrm{~m}$ above pond 1 , and permafrost was found at a depth of $1.2 \mathrm{~m}$. It is therefore evident that the permafrost free areas are small and only exist in connection with the described depressions. The surrounding areas are very rich in periglacial features which indicate normal permafrost conditions.
Fig. 10. Ground temperature curves from pits dug at Vardeborgsletta.

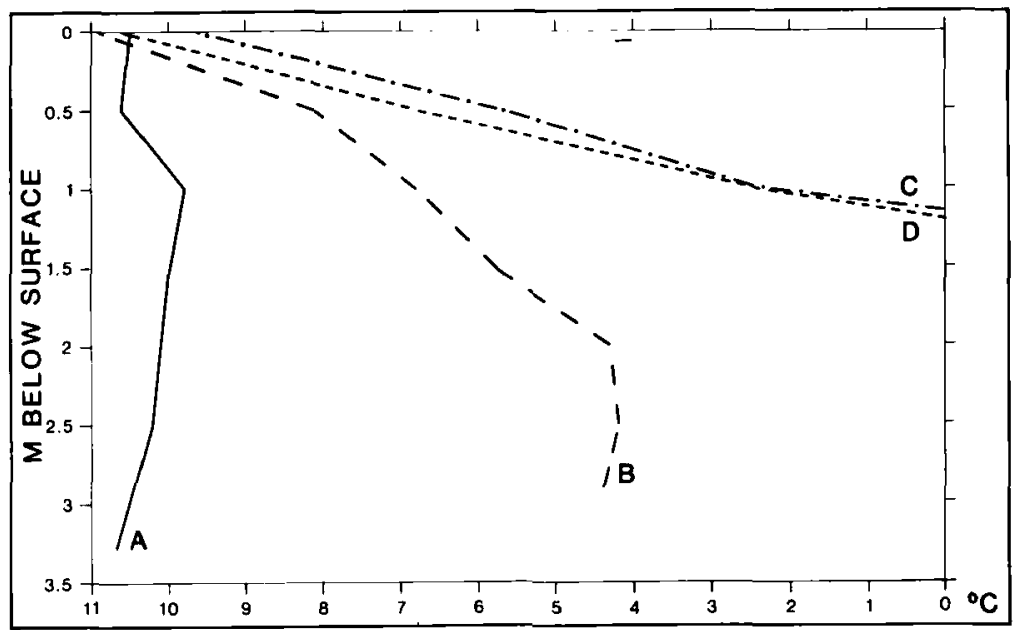




\section{Ground water conditions}

Pits A and B were both dug in coarse sediments near the water level of the ponds, and the bottom of the pits reached more than $2 \mathrm{~m}$ below the ponds' water level (Figs. 4 and 5). In spite of this the pits were dry during the digging as well as during subsequent periods of rainfall. This would suggest that the drainage from the ponds goes vertically downwards through the sediments without spreading horizontally. The bottoms of the ponds usually have a thin layer of clay/silt which slows the percolation so much that ponds are maintained in spite of the coarse underlying sediments. There is, however, no surrounding ground water table in connection with the ponds, and they act as a perched ground water table with water percolating vertically down into the main ground water table. It can be classified as gravitational or vadose water.

The largest discharge of water sinking into the ground can be seen in a swallow hole at pool 4 where a rough estimate of $100 \mathrm{l} / \mathrm{s}$ was made in tributary streams. There are no springs or wells on land where karst water appears, and it probably reaches the sea in subsurface outlets. No such outlets are visible. An attempt was made to trace the water by colouring it with a fluorescence dye. $1 \mathrm{~kg}$ Rodamin B powder was dissolved in 61 technical alcohol and poured into the swallow hole. The water attained a deep red colour, but it was not possible to trace this colour in the sea. The most probable outlet area is at Solovjetskibukta, but dilution of the dye in the subterranean drainage system made any attempts to clarify outlet areas impossible.

\section{Discussion}

As mentioned at the beginning of this paper, the basins have mainly been interpreted as thermokarst formations. This explanation was difficult to accept, and bedrock karst seemed much more likely for the following reasons: 1 . The depressions are too large to have been formed solely during the melting of ice in the ground. 2 . The subsurface drainage system is so extensive that it must include the underlying bedrock. 3 . Bedrock is visible in a few places, mainly along the eastern slope of the trough depression. The rocks are Upper Carboniferous, fossil-rich lime- stones which show varying degrees of surface dissolution.

Outcrops occur in only a few places, but it is still obvious that the basins reach well down into the underlying bedrock. The depressions with ponds 1 to 6 are true karst features caused by large-scale dissolution of mainly limestones. Ponds 7, 8, and 9 have surface outlets, but are probably also mainly solution features in bedrock. Gypsum outcrops between ponds 7 and 8, and karst features in gypsum have been described by Salvigsen et al. (1983).

The age of the depressions and the subsurface drainage system is unknown. If a pre-Holocene system existed, they would have been filled with sediments when the sea covered the area at the beginning of the Holocene. Vardeborgsletta had no permafrost when it emerged from the sea in the early Holocene, and a system of ground water circulation has probably been maintained during the Holocene. The large depressions have probably subsequently been formed when the unconsolidated sediments sunk into collapsing caves and channels in the underlying ground. This process is still active; it can be seen in the steep, eastern slope of the trough depression and in small collapse features near some of the ponds (Fig. 8). A small collapse hollow was formed near pond 5 during our stay there in 1984 .

The ground temperatures measured were exceptionally high compared with other such temperature data available from Svalbard. The permafrost research station at Sveagruva has measured temperatures at a depth of $3 \mathrm{~m}$ to vary between $-5^{\circ} \mathrm{C}$ and $-8^{\circ} \mathrm{C}$ during the year (Bakkehøi 1982). According to Lachenbruch (1968), heat flow from the earth's interior normally results in a temperature increase of approximately $1^{\circ} \mathrm{C}$ per $30-60 \mathrm{~m}$. Similar values have been found in Svalbard in the coal mines (Liestøl 1977). The measurements in pit $\mathrm{A}$ at Vardeborgsletta showed a temperature increase of $1^{\circ} \mathrm{C}$ per $2.5 \mathrm{~m}$. These ground temperature conditions are difficult to explain. One possibility is that water has been forced down to great depths where geothermal heat has been absorbed, and later brought up to a near surface level. In the uppermost layer where the pits were dug, there were neither water nor gas which could have transported the heat, and the heat must therefore have been transported by conduction. The water must penetrate several hundred metres down to obtain a temperature of at least $11^{\circ} \mathrm{C}$, but such water temperatures are 
Table 2. Surface water temperatures in ponds at Vardeborgsletta, 19 July 1984. when the air temperature was about $7.0^{\circ} \mathrm{C}$

\begin{tabular}{ccccccc}
\hline Pond & 1 & 2 & 3 & 4 & 5 & 8 \\
\hline Temp. & 11.0 & 3.4 & 6.6 & 9.6 & 9.4 & 9.8 \\
\hline
\end{tabular}

not unknown from the west coast of Svalbard. Migala \& Sobik (1982) reported a spring in southwest Spitsbergen where a water temperature of $12.3^{\circ} \mathrm{C}$ was measured while the air temperature was $-14.5^{\circ} \mathrm{C}$. Orvin (1944) mentioned springs in the southern part of Spitsbergen with summertime temperatures up to $15^{\circ} \mathrm{C}$.

The origin of the water in thermal springs seems in most cases to be meltwater from higher lying glaciers which is capable of penetrating deep in the ground. In the study area it is possible that meltwater from Vardebreen is responsible for the extremely high ground temperatures encountered (Fig. 2). North of this area there are several places where running and freezing water appears in the winter revealing the occurrence of 'weak' zones in the permafrost ( $\AA$ kerman 1983). Most of them have a connection with the $52 \mathrm{~m}$ deep lake Kongressvatnet, and they are not equivalent to the phenomena at Vardeborgsletta. Surface water temperatures in some ponds at Vardeborgsletta are shown in Table 2. The temperature of ponds without a meltwater supply will be somewhat higher than the air temperature, due to insolation.

\section{Conclusions}

The large-scale karst features are mainly developed in a small area where high ground temperatures make ground water circulation possible. Such features do, indeed, appear to be very limited in Svalbard and other high arctic areas.

The development of dolines with sinking water is mainly a result of the dissolution of carbonate rocks. Thermokarstic processes in the overlying unconsolidated sediments occur and have in many cases been initiated by the bedrock karst. The morphology has thus been modified by, and is to some extent featured by thermokarstic processes.

Variation in drainage capacity and active slope processes connected with the karst features show that karst development takes place at present.
Acknowledgements. - We are grateful to Jonas Åkerman, Stein Erik Lauritzen and Olav Liestøl for critical reading of the manuscript and to Espen Kopperud for preparing the figures.

\section{References}

Bakkehøi, S. 1982: Datainnsamlinger på permasfroststasjonen i Svea, Svalbard. Frost $i$ Jord 24, 3-8.

Baranowski, S. 1974: Report on the Field Work of the Polish Scientific Expedition to Spitsbergen in 1973. Wroclaw. 25 p.

Barbaroux, L. \& Besset, Y. 1968: Le karst de Sarsøyra (Rive Nord Åvatsmarkbre) Vest Spitsbergen. Norois 57, 97-103.

Brook, G. A. 1983: Hydrology of the Nahanni, a highly karsted carbonate terrain with discontinuous permafrost. Permafrost: Fourth International Conference, Proceedings, 86-90.

Brook, G. A. \& Ford, D. C. 1978: The origin of labyrinth and tower karst and the climatic conditions necessary for their development. Nature 275, 493-496

Corbel, J. 1957: Les karst du nord-oust de l'Europe. Inst. Etudes Rhondaniennes de l'Université de Lyon, Mem. et doc. 1. $544 \mathrm{p}$.

Corbel, J. 1960: Nouvelles recherches sur les karst arctiques Scandinaves. Z. Geomorph. N. E. Supp. 2, 74-78.

Corbel, J. 1964: Les karst des régions polaires. Revue Belge de Geographie 1-2, 83-103.

Flood, B., Nagy, J. \& Winsnes, T. S. 1971: Geological map Svalbard 1:500,000, Sheet $1 \mathrm{G}$ Spitsbergen Southern part. Norsk Polarinst. Skr. 154a.

Gogolek, W. \& Lewandowski, W. 1980: Preliminary geomorphological characteristics of Linnédalen (Spitsbergen, Svalbard Archipelago). Pol. Polar Res. 1 (4), 7-19.

Helldén, U. 1974: Some calculations on the denudation in the dolomitic limestone area at Isfjord-radio, West Spitsbergen. Nor. Geogr. Tidsskr. 28, 83-88.

Lachenbruch, A. 1968: Permafrost. Pp. 833-838 in Fairbridge, R. W. (Ed.): Encyclopedia of Geomorphology. Reinhold, New York.

Liestøl, O. 1977: Pingos, springs and permafrost in Spitsbergen. Norsk Polarinst. Årbok 1975, 7-29.

Migala, U. \& Sobik, M. 1982: Discovery of thermal springs in the Raudfjellet region, SW Spitsbergen. Polar Research 2, 109-110.

Orvin, A. K. 1944: Litt om kilder på Svalbard. Norsk Geogr. Tidsskr. $X(1), 16-38$.

Palmer, A. N. 1984: Objectives and current status of alpine and arctic karst research. Norsk Geogr. Tidsskr. 38, 145-150.

Popov, I. V., Gvozdetskiy, N. A., Chiksishev, A. G. \& Kudelin, B. I. 1972: Karst in U.S.S.R. Pp. $355-416$ in Herak \& Stringfield (Eds.): Karst. Elsevier.

Pulina, M. 1974: Preliminary studies on denudation in SW Spitsbergen. Bull. Akad. Pol. Sc. S. Terre 22, 83-89.

Salvigsen, O., Lauritzen, $\emptyset$. \& Mangerud, J. 1983: Karst and karstification in gypsiferous beds in Mathiesondalen, Central Spitsbergen, Svalbard. Polar Research 1 n. s.. 83-88.

Steffensen, E. L. 1982: The climate of the Arctic Stations. Klima 5, $44 \mathrm{p}$.

Worsley, D. \& Mørk, A. 1981: Excursion Guide to Isfjorden, Svalbard. IKU, $55 \mathrm{p}$.

Akerman, H. J. 1980: Studies of periglacial geomorphology in West Spitsbergen. Meddelanden fràn Lunds Univ. Geogr. inst. Ser. Avh. LXXXIX, $297 \mathrm{p}$.

Åkerman, J. 1983: Notes on chemical weathering, Kapp Linné, Spitsbergen. Permafrost: Fourth International Conference Proceedings, 10-15. 